\title{
Solid Phase Peptide Synthesis of Some Analogs of Bradykinin Hormone Using Microwave Energy Application (part II)
}

\author{
M. A. Zewail $\#$, A. M. Naglah, and S. M. Osman \\ Peptide Chemistry Department, National Research Centre, \\ Cairo,Egypt.
}

\begin{abstract}
7 HREE analogs of Bradykinin, $\left(\mathrm{Cys}^{6,8}\right) \mathrm{BK},\left(\mathrm{Cys}^{2,5}\right) \mathrm{BK}$ and (Cys $\left.{ }^{1,9}\right)$ BK were synthesized by modified solid phase peptide synthesis with the application of microwave energy. The effect of the replacement of; $\mathrm{Ser}^{6}$ and $\mathrm{Phe}^{8}$ by $\mathrm{Cys}^{6,8}, \mathrm{Pro}^{2}$ and $\mathrm{Phe}^{5}$ by Cys ${ }^{2,5}$, and $\mathrm{Arg}^{1,9}$ by $\mathrm{Cys}^{1,9}$ on the biological activity of bradykinin was investigated. A continued work of a previously done study includes synthesis of three BK analogs, (Lys $\left.{ }^{1}\right)$ BK, $\left(\operatorname{Lys}^{9}\right)$ BK and (Lys ${ }^{1,9}$ ) $\mathrm{BK}$, using the modified solid phase peptide synthesis with microwave energy. The six analogues have been tested in vitro for their effect on heart rate and in isolated organ for the arterial pressure of rats.
\end{abstract}

Keywords: Bradykinin, Modified solid phase peptide synthesis and Microwave energy.

Bradykinin (BK) is a nonapeptide, (Arg-Pro-Pro-Gly-Phe-Ser-Pro-Phe-Arg), involved in various physiological and pathophysiological processes ${ }^{(1)}$, particularly as an initiator of inflamation . BK, a member of polypeptides called kinins, was discovered by Rocha et al. ${ }^{(2)}$ and isolated later by Ellioe et $a l{ }^{(3)}$. It is produced in the body in response to many kinds of injuries and inflammatory insults. It is the most potent known elicitor of pain ${ }^{(4)}$.

Activities of BK are mediated by kinin receptors expressed in almost all cells in the majority of species. These receptors belong to the G-protein coupled family and their activation stimulates smooth muscle cells, sensory nerve endings, causes vasodilatation and microvascular leakage and modulates the response of immunocompetent cells.

BK is also best known as a mediator of inflammatory responses and initiator of peripheral pain signal ${ }^{(4)}$. Two types of receptors, designated B1 and B2, mediate the biological activities of BK. B2 receptors are very widely expressed in most tissues and require the entire BK sequence for recognition. $\mathrm{B} 1$ receptors recognize and bind des-Arg9-BK only and their expression is rapidly induced by inflammatory stimulation ${ }^{(5)}$.

\# Corresponding author, E-mail: Zewail 40@yahoo.com 
The synthesis of BK analogues for structure-activity studies started shortly after the announcement of the structure of this hormone in 1960. However, the first report on bradykinin analogues able to antagonize the effects of BK in standard kinin assays, such as rat uterus, guinea pig ileum or rat blood pressure, only came 25 years later, with the description of [D-Phe7]BK and [Thi5,8,DPhe7]BK ${ }^{(6)}$.

Hundreds of analogues with single or multiple substitutions were later designed and synthesized in many laboratories ${ }^{(7)}$. In the course of these studies the role of amino acid residues in all positions of BK, as well as the influence of various combinations of substitutions on the pharmacological activity of the resulting compounds were carefully investigated. A major improvement in the potency of BK antagonists was achieved in 1991, when potent B2 blockers, carrying conformationally constrained amino acid residues of their C-terminal ends, were synthesized ${ }^{(8,9)}$.

On the basis of comparison of the circular dichroism (CD) spectra of several analogs of BK, the presence of an intramolecular $3 \rightarrow 1$ hydrogen bond between the carbonyl oxygen of Ser6 and the amide proton of Phe8, an intramoleculr $4 \rightarrow 1$ hydrogen bond between the carbonyl oxygen of Pro 2 and the amide proton of Phe 5 and a salt bridge between the guanidino group of Arg1 and the carboxyl group of Arg9 was emphasized ${ }^{(10)}$. It was found that all of the peptides analogues of bradykinin of high biological activity, exhibited CD spectra like that of bradykinin, so it appears unlikely that highly ordered peptides of the same amino acids composition as bradykinin would possess bradykinin-like effects $^{(11)}$.

In the present study analogues of bradykinin was synthesized using microwave assisted solid phase peptide synthesis ${ }^{(12-14)}$. The solid phase approach is a well established method for synthesizing peptides since the work of Bruce Merrifield in the $1962^{(15,16)}$. Since the first serious experiments for synthesizing peptides with the help of microwaves in 1992, the method and the instruments have been optimized a lot. Nevertheless many peptide chemists around the world still think of "cooking peptides" when they hear of microwave assisted peptide synthesis (MAPS) and fear the enhancement of side-reactions. Many examples of synthesized peptides from many laboratories show that MAPS is definitely a valuable tool for synthesizing peptides and that there is no need to fear the side-reactions ${ }^{(17)}$.

The present work was carried out to further investigate the effect of the presence of the intramolecular $3 \rightarrow 1$ and $4 \rightarrow 1$ hydrogen bonds in the structure of

Egypt. J. Chem. 56, No. 2 (2013) 
BK in solution. Moreover, the effect of Cys residues on bradkinin stability and biological activity was studied.

\section{Chemistry}

The synthesis was carried out on polystyrene - polyethylene glycol (PSPEG3000) graft co-polymer as the polymeric support. The polymer was synthesized as described by Rapp et al. ${ }^{(18)}$.

Fmoc amino acids were synthesized according to Carpino et al.$^{(19)}$. The side chain of Arg was protected by methoxytrimethyl phenyl sulfonyl (MTR), and of Ser and Cys, with t.Butyl (tBu).

The microwave oven was a $10 \%$ of its total power and with nitrogen bubbling (inert gas for stirring).

Coupling steps were performed through the DIC/HOBT activation method using microwave irradiation ${ }^{(20)}$.

\section{Results and Discussion}

The following peptide chains were synthesized using the modified solid phase peptide synthesis (MSPPS) method with microwave technique application :

1. $\mathrm{H}_{2} \mathrm{~N}$-Arg-Pro-Pro-Gly-Phe-Cys-Pro-Cys-Arg-OH

2. $\mathrm{H}_{2} \mathrm{~N}$-Arg-Cys-Pro-Gly-Cys-Ser-Pro-Phe-Arg-OH

3. $\mathrm{H}_{2} \mathrm{~N}$-Cys-Pro-Pro-Gly-Phe-Ser-Pro-Phe-Cys-OH

The essential advantages of the microwave assisted solid phase peptide synthesis are that the reduction of coupling and deprotection required time, the decreasing of the racemization and the excellent purity of the crude peptide.

The time required for complete coupling and deprotection reactions for the first amino acids and percentage of the resin capacity in the synthesized sequences (IV-VI) by MSPPS using MW energy is indicated in the following Table:

\begin{tabular}{|c|c|c|c|}
\hline Fmoc-A.A & $\begin{array}{c}\text { \% of maximum } \\
\text { coupling capacity }\end{array}$ & $\begin{array}{c}\text { Time required for } \\
\text { maximum } \\
\text { coupling in min }\end{array}$ & Deprotection \\
\hline Fmoc-Arg & 94 & 10 & 4 \\
\hline Fmoc-Cys & 92 & 6 & 3 \\
\hline
\end{tabular}

Egypt. J. Chem. 56, No. 2 (2013) 
9-Flurenyl methoxycarbonyl (Fmoc) group was used as $\mathrm{N}$ - terminal protecting group. It enables the UV spectroscopic monitoring of the coupling and deprotection reactions.

The purity of the obtained peptide chains was proved by correct amino acid analysis and the $\mathrm{mz}$ values of the mass spectroscopy. The functionality of the characterized peptides was investigated using IR spectroscopy.

Peptide4 (BKIV): H2N-Arg-Pro-Pro-Gly-Phe-Cys-Pro-Cys-Arg-OH (MS: $\mathrm{m} / \mathrm{z}$ 1032.24)

Amino acid analysis:

\begin{tabular}{|c|c|c|c|c|c|c|}
\hline & Arg & Pro & Gly & Phe & Cys & Arg \\
\hline Calcd. & 2 & 3 & 1 & 1 & 2 & 2 \\
\hline Found & 1.9 & 2.5 & 0.7 & 1 & 1.3 & 1.9 \\
\hline
\end{tabular}

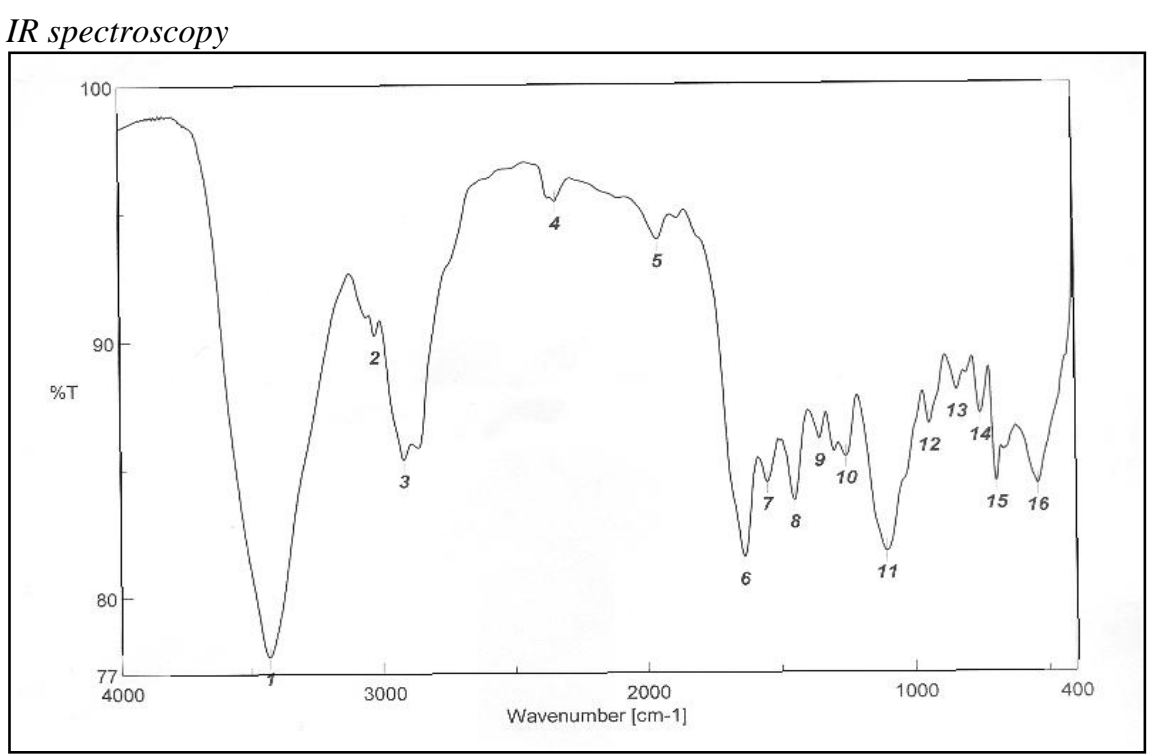

Peptide5 (BKV): $\mathrm{H}_{2} \mathrm{~N}$-Arg-Cys-Pro-Gly-Cys-Ser-Pro-Phe-Arg-OH (MS: m/z 1022.21)

Amino acid analysis

\begin{tabular}{|c|c|c|c|c|c|c|}
\hline & Arg & Cys & Pro & Gly & Ser & Phe \\
\hline Calcd. & 2 & 2 & 2 & 1 & 1 & 1 \\
\hline Found & 1.8 & 1.6 & 1.5 & 0.83 & 0.72 & 1 \\
\hline
\end{tabular}

Egypt. J. Chem. 56, No. 2 (2013) 

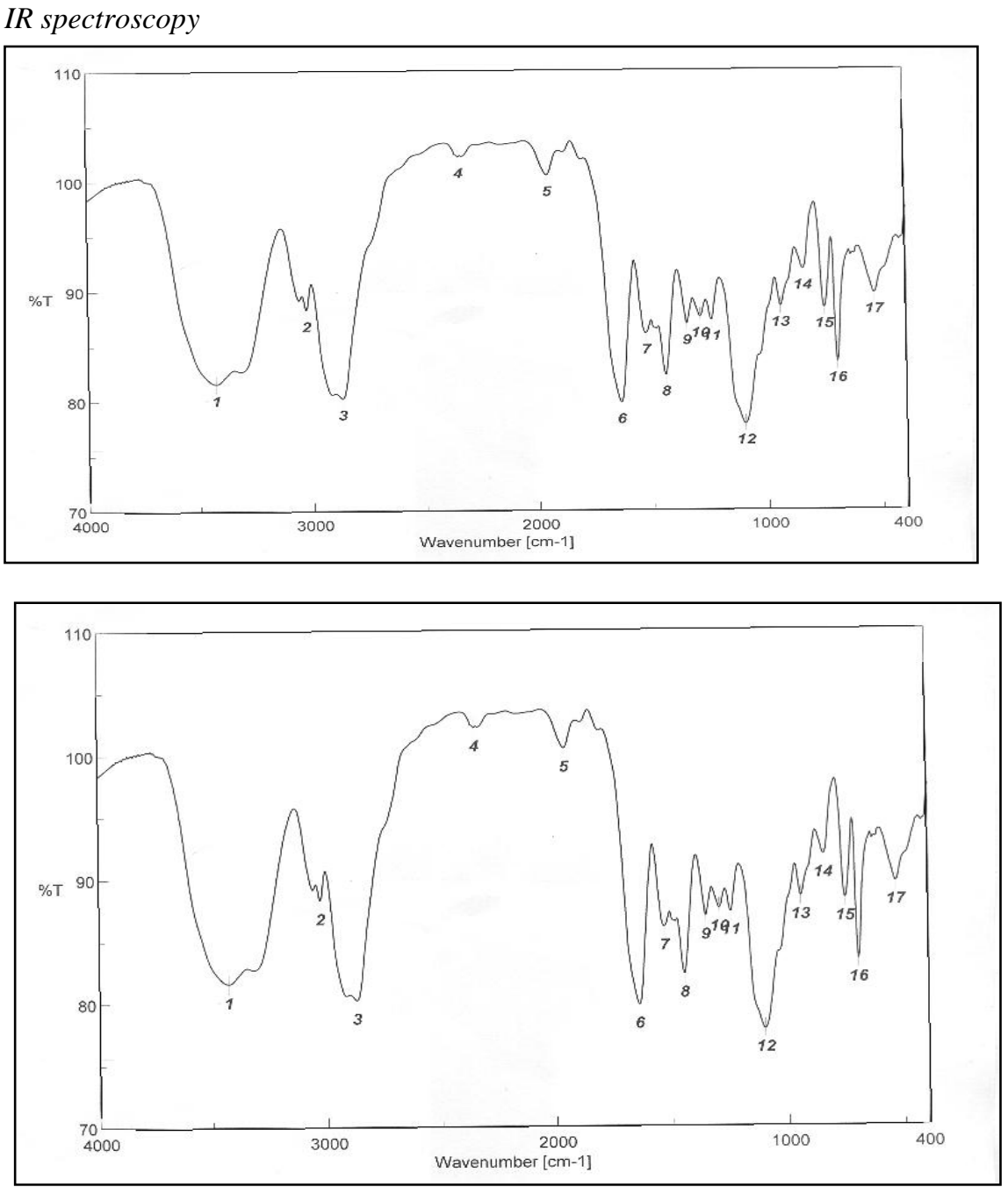

Peptide6 (BKVI): H2N-Cys-Pro-Pro-Gly-Phe-Ser-Pro-Phe-Cys-OH (MS: $\mathrm{m} / \mathrm{z}$ 954.12)

Amino acid analysis

\begin{tabular}{|c|c|c|c|c|c|}
\hline & Cys & Pro & Gly & Phe & Ser \\
\hline Calcd. & 2 & 3 & 1 & 2 & 1 \\
\hline Found & 1.6 & 2.2 & 0.8 & 2 & 0.72 \\
\hline
\end{tabular}


The results indicated that the replacement of the first amino acid Arg with Lys amino acid affected the time of coupling and deprotection in microwave and the percentage of maximum coupling capacity of the amino acid.

The increased time taken by Fmoc-Arg in microwave for coupling, beside the effect of Fmoc group, due to the presence of guanidine group that leads to a steric hindrance that hinders the reaction between the resin beads and the amino acid.

\section{Biological Evaluation}

Investigation of the effect of the peptide candidates on the heart rate

The following chart represents the change in the heart rate for each peptide sequence:

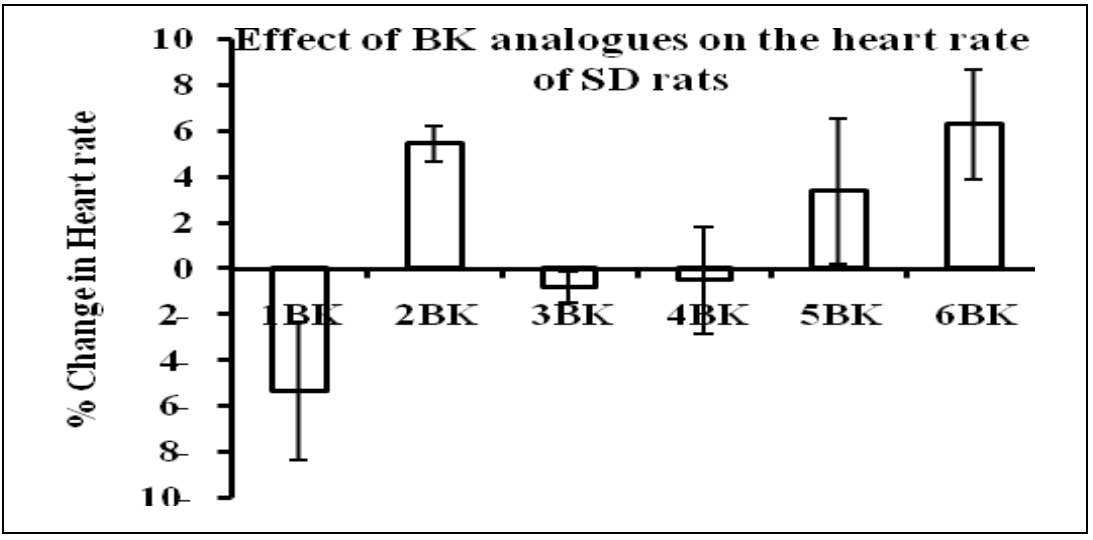

Investigation of the effect of the peptide candidates on the smooth muscles

The following chart represents the maximum in the relaxation in aortic ring for each peptide sequence:

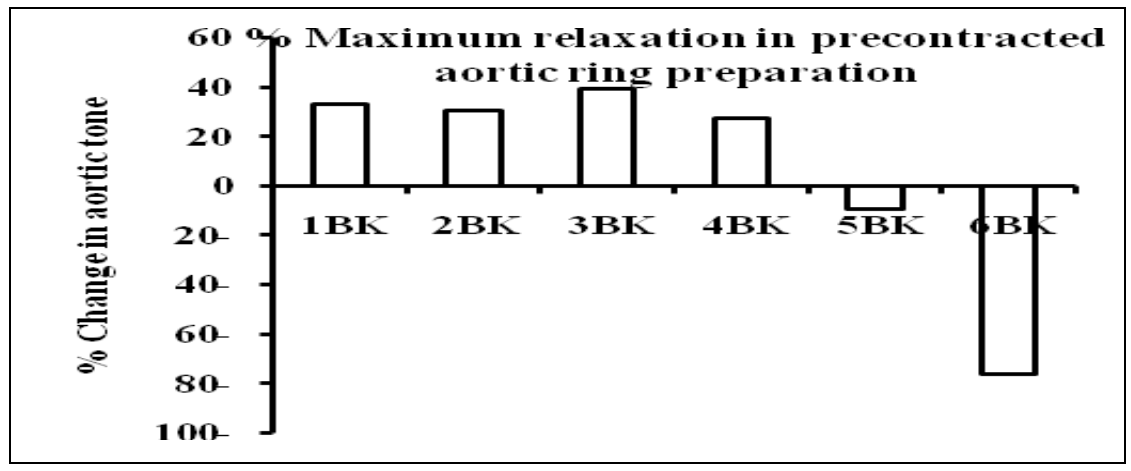

Egypt. J. Chem. 56, No. 2 (2013) 
The results obtained from the two assays revealed the following significant criteria:

1. BKVI is considered the most potent vasodilator among all synthesized $\mathrm{Bk}$ analogs at dose range $\left(10^{-4}-10^{-3}\right)$ using precontracted aoretic ring preparation.

2. BKII showed an accepted vasodilatation effect at dose range $\left(10^{-4}-10^{-3}\right)$, using precontracted aoretic ring preparation.

3. BKV showed marginal vasodilatation effect at dose range $\left(10^{-4}-10^{-3}\right)$, that might be improved at higher dose ranges.

4. BKII, BKV and BKVI induced vasodilatation resulted in natural physiological reflux tachycardia corresponding to its vasodilatation efficacy.

5. All other BK analogs failed to block nor-epinephrene enduced aortic ring contraction. However, they may block BK relaxation.

6. BKI induced bradycardia might be attributed to central effect (cardiovascular depression effect).

Approaching a qualitative structure/activity relationship for the peptide candidates

1. The peptide sequences BKI, BKII, BKIII and BKVI are designed to investigate the effect of the salt bridge between the guanidine group of $\operatorname{Arg}^{1}$ and the carboxyl group $\mathrm{Arg}^{9}$ in the main bradykinin sequence, thereby, the previous results revealed that:

i. Replacing of $\operatorname{Arg}^{1}$ with Lys, as in BKI, shows bradykinin antagonistic effect, that may indicate that the salt bridge between $\mathrm{Arg}^{1}$ and $\mathrm{Arg}^{9}$ in the bradykinin sequence is important for its action and that bridge did not formed in the case of replacing of $\operatorname{Arg}^{1}$ with Lys.

ii. Replacing of $\mathrm{Arg}^{9}$ with Lys, as in BKII, shows bradykinin agonistic effect, that may be attributed to the salt bridge formed between the guanidino group of $\operatorname{Arg}^{1}$ and the carboxyl group of Lys ${ }^{9}$.

iii. Replacing of both $\operatorname{Arg}^{1}$ and $\operatorname{Arg}^{9}$ with Lys moieties, as in BKIII, did not show any bradykinin agonistic or antagonistic effects and that may be attributed to the disappearance of the salt bridge between Lys ${ }^{1}$ and Lys 9 .

iv. Replacing of both $\operatorname{Arg}^{1}$ and $\operatorname{Arg}^{9}$ with Cys moieties, as in BKVI, showed a significant agonistic effect that may be attributed to the disulfide bond formed between the two-thiol groups of $\mathrm{Cys}^{1}$ and $\mathrm{Cys}^{9}$.

2. The peptide sequence BKIV is designed to investigate the effect of the intramolecular $3 \rightarrow 1$ hydrogen bond between the carbonyl oxygen of $\mathrm{Ser}^{6}$ and the amide proton of $\mathrm{Phe}^{8}$ in the main bradykinin molecule, by that, the previous data indicate that:

$>$ Replacing of both $\mathrm{Ser}^{6}$ and $\mathrm{Phe}^{8}$ with Cys moieties did not show any bradykinin agonistic or antagonistic effects that may attribute to the disappearance of the hydrogen bond and to the non-effective action of the 
formed disulphide bond between the two-thiol groups of $\mathrm{Cys}^{6}$ and $\mathrm{Cys}^{8}$ in the synthesized peptide.

3. The peptide sequence BKV is designed to investigate the effect of intramolecular $4 \rightarrow 1$ hydrogen bond between the carbonyl oxygen of $\mathrm{Pro}^{2}$ and the amide proton of Phe $\mathrm{P}^{5}$ in the main bradykinin molecule, thereby, the pre-mentioned data revealed that:

1. Replacing of both $\mathrm{Pro}^{2}$ and $\mathrm{Phe}^{5}$ with Cys moieties showed marginal potency and tends to have a bradykinin agonistic effect at higher doses. That may attribute to the formed disulphide bond between the two-thiol groups of $\mathrm{Cys}^{2}$ and $\mathrm{Cys}^{5}$ in the synthesized peptide.

\section{Experimental}

Attachment of the first amino acid to the resin

A solution of (0.026 gm, $0.195 \mathrm{mmol}) \mathrm{HOBt},(0.195 \mathrm{mmol})$ Fmoc-amino acid and (0.024 gm, $0.195 \mathrm{mmol}, 0.03 \mathrm{ml})$ DIC and a catalytic amount of DMAP in $2 \mathrm{ml}$ DMF was shacked at r.t. for $10 \mathrm{~min}$ then was added to a swelled suspension of (0.1 gm, $0.48 \mathrm{meq})$ PS-PEG3000-NH2 in $2 \mathrm{ml}$ DMF. The mixture was then subjected to MW irradiation until Kaiser Test showed a negative result. Then, the resin was filtered off and washed several times with DMF, DCM, DMF, DCM, MeOH and ether.

The Fmoc deprotection occurred by adding $2 \mathrm{ml}$ of $25 \%$ piperidine/DMF solution to the Fmoc-A.A- resin suspension in DMF and the mixture was then heated in MW oven till Kaiser test gave positive result. The solution was then filtered off and washed several times with DMF, DCM, DMF, DCM, MeOH and ether. The capacity of coupling was checked by U.V detection of Fmoc group, It was about 94\% for Fmoc-Arg(mtr) and 92\% for Fmoc-Cys(tBut).

Synthesis of the peptide sequences

The second amino acid Fmoc-A.A-OH was coupled to the first amino acid attached to the polymer by adding a solution of $(0.096 \mathrm{mmol})$ Fmoc-A.A-OH, (0.013 gm, $0.096 \mathrm{mmol}) \mathrm{HOBt},(0.024 \mathrm{gm}, 0.096 \mathrm{mmol}, 0.015 \mathrm{ml})$ DIC and a catalytic amount of DMAP in $2 \mathrm{ml}$ DMF to a swelled suspention of amino freed first amino acid- polymer. The mixture was then heated in MW oven until Kaiser Test showed the required result. The resin was then filtered off and washed several times with DMF, DCM, MeOH and ether.

Coupling of Fmoc-A.A's was carried out as indicated above using $0.096 \mathrm{mmol}$ of each protected amino acid.

The coupling and deprotection steps were monitored by Kaiser Test ${ }^{(21)}$ and UV test ${ }^{(22)}$ was used for coupling capacity.

Egypt. J. Chem. 56, No. 2 (2013) 


\section{Cleavage of the synthesized peptides from the resin}

The cleavage of the polymeric support and isolation of the free peptides were carried out using $1 \mathrm{M}$ aq. $\mathrm{NaOH}^{(23)}$ after its treatment with $95 \%$ aq.TFA to remove the side-chain protecting groups by shaking the peptide resin at R.T. for one hour then isolation of the resin by filtration under reduced pressure and washing with TFA, the filtrate then discarded and the resin is washed with DCM, $10 \%$ DIPEA in DCM and DCM and left to dry under vacuum. The dry resin is then pre-swelled in dioxane and a cold $1 \mathrm{M} \mathrm{NaOH} /$ Dioxane $(1: 3,20$ $\mathrm{ml} / \mathrm{gm}$ ) solution is added and shacked for $15 \mathrm{~min}$ at R.T. the resin is then filtered into a flask contains $1 \mathrm{M} \mathrm{HCl}(5 \mathrm{ml} / \mathrm{gm})$, this flask should be cooled in an ice bath to prevent warming as the base solution is neutralized, the resin is then washed with water and the $\mathrm{pH}$ of the filtrate is adjusted to 7.0. The filtrate is then washed with diethylether to get red of any impurities and unwanted small peptides. The water residue is then lyophilized and the desired peptide was obtained.

The synthesized peptides were characterized using FAB mass and ESI Mass spectroscopy, IR spectra and amino acid analysis as indicated in the next section.

\section{Biological Evaluation}

Determination of the effects of the synthesized peptide analogues [BKI, BKII, and BKIII], on the heart rate [HR] and on the smooth muscles (aortic ring) was realized in Pharmacology Department, National Research Centre.

\section{Evaluation of the action on the heart rate}

About $300 \mathrm{gm} \mathrm{SD}$ rats were anesthetized with intrapretonial (i.p) injection of thiopental $(100 \mathrm{mg} / \mathrm{kg})$. Tail veins were canulated and BK analogues were injected $(600 \mathrm{mg} / \mathrm{kg})$. ECG [Electrocardiography] was recorded for about $5 \mathrm{~min}$. before and after drug administration and heart rates were compared. Confidence interval test was used to evaluate significance with $\alpha=0.05$.

Evaluation of the action on the smooth muscles (aortic ring)

About $400 \mathrm{gm}$ SD rats were euthanized by cervical dislocation and segments from the aorta were isolated and hanged in balanced Kreb's solution under static tension of $2 \mathrm{~g} / \mathrm{segment}$ in thermostatic water jacketed isolated organ bath, UgoBasile, Italy. Aortic segments were precontracted with Nor-epinephrin $(0.4 \mu \mathrm{g} / \mathrm{ml})$ followed by application of the test compounds in the dose range of $10^{-4}-10^{-3} \mathrm{M}^{(24)}$. Changes in N.E. induced contractile cascade in aortic ring were monitored and $\%$ change in muscle tones was calculated. 
Thermostatic organ bath records before and after treatement with BK analogues are showed as followes:

BKIII: \% Change in muscle tones $=39.3 \%$

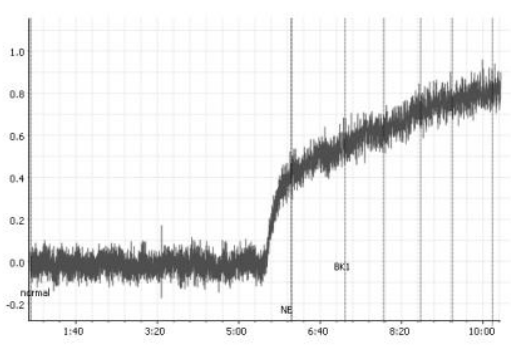

BKI: \% Change in muscle tones $=33.1 \%$

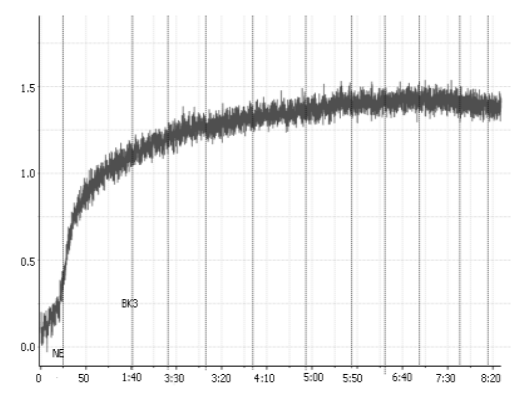

BKIII: \% Change in muscle tones $=39.3 \%$

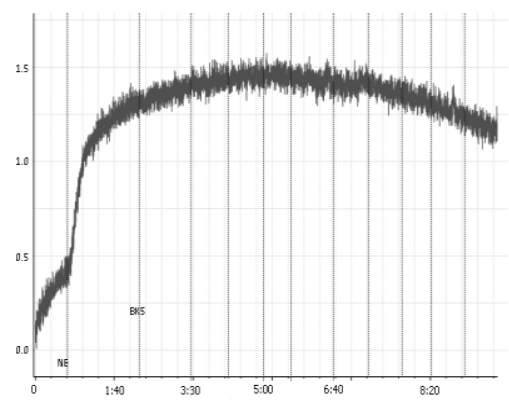

BKV: $\%$ Change in muscle tones $=-9.2 \%$

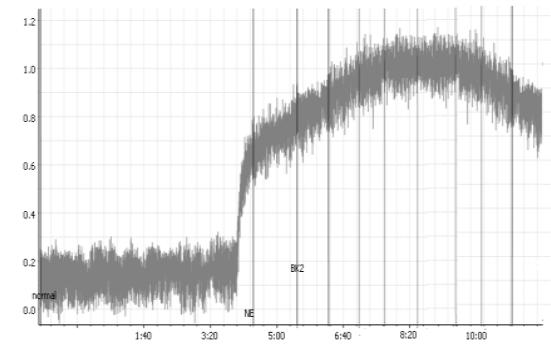

BKII: $\%$ Change in muscle tones $=30.6 \%$

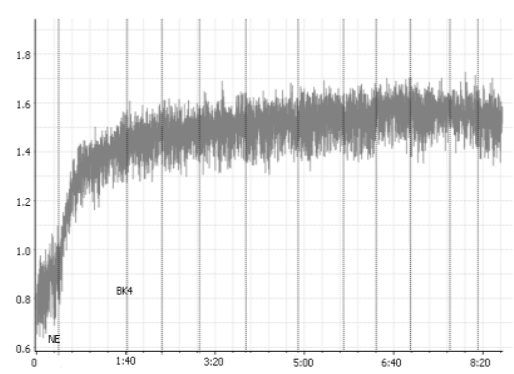

BKIV: $\%$ Change in muscle tones $=27.6 \%$

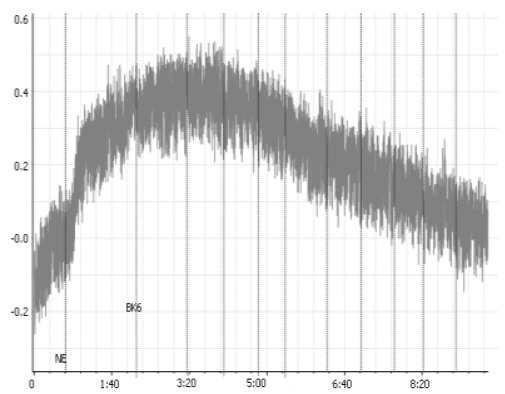

BKVI: \% Change in muscle tones $=-76.2 \%$

Egypt. J. Chem. 56, No. 2 (2013) 


\section{References}

1. Zewail, M.A., Khalil, E.M., Mohamed, Shaimaa M. and Sharada, Hayat M.,Synthesis of some analogs of bradykinin hormone using modified solid phase peptide synthesis and microwave technique (part 1). Egypt. J. Chem. 2 (53), 267-278 (2010).

2. Rocha M. Silva, Beraldo, W. T. and Rosenfeld, G., Bradykinin, a hypotensive and smooth muscle stimulating factor released from plasma globulin by snake venoms and by trypsin. Am. J. Physiol. 156, 261-273 (1949).

3. Elliott, D.F. Lewis, G.P. and Horton, E. W., Biochem. Biophys. Res. Comm. 3, 87 (1960).

4. Stewart, J.M., The kinin system in inflammation agents actions. 42s, 145-57 (1993).

5. Bhoola, K.D., Figueroa C.D. and Worthy, K., Bioregulation of kinins: Kallikreins, kininogens and related kininases. Pharmacol. Rev. 44, 1-78 (1992).

6. Vavrek, R.J. and Stewart, J.M., Competitive antagonists of bradykinin. Peptides, 6, 161-166 (1985).

7. Stewart, J.M. and Vavrek, R.J., The pharmacology of bradykinin receptors. In: Bradykinin Antagonists. Basic and Clinical Research (Burch RM, Ed.) pp. 51-96. Marcel Dekker Inc., New York-Basel-Hong Kong (1991).

8. Hock, F.J., Wirth, K., Albas, U., Linz, W., Gerhards, H.J., Wiemer, G., Henke, St., Breipohl, G., Konig, W., Knolle, J. and Scholkens, B.A., A New potent and long acting bradykinin antagonists. Br. J. Pharmacol. 102, 769-773 (1991).

9. Stewart, J., Gera, L., Hanson, W., Juzack, J., Burkard, M., Mc Cullough, R., and Whalley E.T., A new generation bradykinin antagonists. Immunopharmacology, 33, 51-60 (1996).

10. Abdel Rahman, Somaya E., Evaluation of the action of BK analogues on the heart rate. Zagazeeg J. Pharm. Sci. 4(1), 18-24 (1995).

11. Brady, A.H., Ryan, J. W. and Stewart, J. M., Circular dichroism of bradykinin and related peptides. Biochem. J. 121, 179-184 (1971).

12. Collins, Jonathan, Collins Jr., Michael, J., Singh, Sandeep K., Vanier, Grace, Merriweather, Hillary, Douglas, Alicia and Cox. Zachary, J., Recent developments in microwave enhanced solid phase peptide synthesis. The $2^{\text {nd }}$ AsiaPacific International Peptide Symposium (2007).

13. Basso, Alessandra, Sinigoi, Loris, Gardossi, Lucia and Flitsch, Sabine, Effect of microwave radiation on enzymatic and chemical peptide bond synthesis on solid phase. International Journal of Peptides (1-4) (2009). 
14. Abdel Rahman, S., Mohamed, Nagla, A. and Amin, Rasha A., Synthesis and conformational analysis of some erythropoitien mimetic peptides using microwave energy. Egypt. J. Chem. 3 (53), 435-448 (2010).

15. Merrifield, R.B., Solid phase peptide synthesis; The synthesis of tetra- peptides.

16. Zewail M. A., Synthesis of two modified peptides fragments of B- chain insulin to be used in the semi- synthesis of insulin. Bull. NRC, Egypt, 3, 217-226 (1978).

17. Andreas Rybka and Frank, Hans-Georg, Microwave assisted peptide synthesis- a tool to replace classica SPPS. American Peptide Society (2005).

18. Rapp, W., Zhang, L., Habich, R. and Bayer, E., In: G. Jun and E. Bayer (Ed.): Peptides (1988)

19. Carpino, L.A. and Han, G.Y., J. Am. Chem. Soc. 5748 (1976).

20. Naglah, A.M. , The application of microwave irradiation technique in the synthesis of some peptide fragment analogs of insulin B-chain. Ph.D Thesis, Zagazig University, Egypt (2008).

21. Kaier, E., Colescott, R.L., Bossinger, C.D. and Cook, P., Anal. Biochem. 34, 595-598 (1970)

22. Meienhofer, J., Waki, M., Heimer, E.P., Lambros, T.J., Makofsake, R.C. and Chi-Deu Chang, Int. J. Peptide Protein Res. 13, 35-42 (1979).

23. Atherton, E. and Sheppard, R.C., "Solid Phase Peptide Synthesis: A Practical Approach", IRL Press, Oxford. (1989).

24. Labudda, O., Wierzba, T., Sobolewski, D., Sleszynska, M., Gawinski, L., Plackova, M., Slaninova, J. and Prahl, A., Acta Biochimica. Polonica., 54, 1 (2007). 
إستخدام طريقة السطح الصلب الحديثة فى تثبي بعض متشابهات هرمون البراديكينين مع تطبيق تقنية الميكروويف الصنف

محمد على زويل ، أحمد نجلة و شيماء عثمان القئل

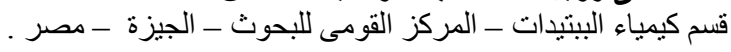

يهدف هذا البحث الى تثييد بعض منشابهات هرمون البراديكينين نظر الأهميته

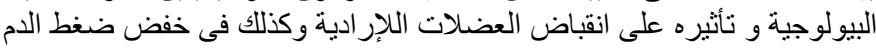
و غير ذلك من العمليات الحيوية داخل النياف العنم .

وقد تم تشييد السلاسل البيتيدية المعنية بإستخدام الطرق المستخدمة فى المي

تحضير البيتيديات المعنية بإستخدام أحدث الاوساط الصنية الصلبة و بتطبيث تقنية

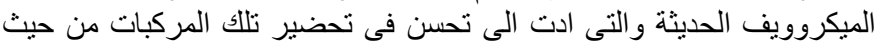

زمن حدوث التفاعلات و درجة نقاوة المركبات المحضرة وكذلت كمية الناتج .

كما تم اختبار فاعلية المركبات المشيدة على معدل ضربات القلب وتأثثر ها

على ضغط الدم (إنبساط الاو عية) 